\title{
Implementation of Regional Revenue Management Agency in Increasing Regional Original Income of Semarang Regency
}

\author{
Mutmainah $^{1}$, Riswadi ${ }^{2}$ \\ \{muthmainnahmursalinsamad72@gmail.com¹, riswadi@borobudur.ac.id² $\}$ \\ Universitas Borobudur, Jakarta, Indonesia ${ }^{1,2}$
}

\begin{abstract}
The purpose of this study is to determine the Regional Revenue Management Agency's duties and authorities in order to increase Semarang Regency's Regional Original Revenue, as well as the Regional Policy to Increase Regional Original Revenue implemented by the Semarang Regency Regional Revenue Management Agency. This is a form of research that takes place at a library. The problem, as well as the literature in journals, books, and research reports, provide the facts or resources needed to complete the analysis. The major task of the Regional Revenue Management Agency (BP2D), according to the findings of this study, is to carry out regional government issues based on autonomy and assistance tasks.
\end{abstract}

Keywords: Implementation; Duties and Authorities; Regional Income

\section{Introduction}

The Republic of Indonesia's Constitution, adopted in 1945, specifically states that the country is a legal state. In accordance with these rules, one of the fundamental foundations of the rule of law is the guarantee of equality before the law for all people (equality before the law). As a result, everyone has the right to equal treatment before the law, as well as fair legal recognition, assurance, protection, and certainty [1].

The Fourth Amendment to the Constitution of the Republic of Indonesia, enacted in 2002, hints at the concept of the State of Law, or "Rechtsstaat," which was previously only stated in the Explanation to the Constitution of the Republic of Indonesia, enacted in 1945, and enshrined in Article 1 paragraph (3), which states, "The State of Indonesia is the State of Law "[2]". In the State of Law concept, it is idealised that what must be made commander in chief in the dynamics of state life is law, not politics or economics. The application of the Indonesian state of law principle, on the other hand, is based on elements of the state of law in general, such as the existence of efforts to protect human rights, the separation or division of powers, the implementation of people's sovereignty, government performance based on applicable laws and regulations, and the existence of state administrative justice. All of these factors must be utilized consistently in order to fulfill the objectives of the State of Indonesian law as sought in the Opening of the Constitution of the Republic of Indonesia 1945 [3]. 
The Opening of the Constitution of the State of Republik Indonesia 1945 lays forth the goals of the Unitary State of the Republic of Indonesia. "Then to form a government of the State of Indonesia that protects the entire Indonesian nation and all Indonesian blood, and to promote the general welfare, educate the nation's life, and participate in the implementation of a world order based on independence, lasting peace, and social justice..." begins the fourth paragraph. Although the administrative system of the State of Indonesia is the duty of the government, it also requires the viewpoints and aspirations of the community. This will encompass the people's view of life about the people's level of prosperity and well-being, which is accommodated in a regional autonomy [3]. In line with that, the Constitution of the Republic of Indonesia 1945 has regulated it in Article 18 Paragraphs 1-7, 18A Paragraphs 1 and 2, and $18 \mathrm{~B}$ paragraphs 1 and 2. Regional autonomy is enforced in Indonesia through, Local Government Law No. 23 of 2014 of the Republic of Indonesia. Law No. 9 of 2015 on the Second Amendment to Law No. 23 of 2014 on Local Government and Government Regulation No. 18 of 2016 on Regional Devices have both recently been revised.

For this reason, the Government of Semarang regency has issued Semarang Regency Regional Regulation No. 21 of 2016 concerning the Establishment and Arrangement of Semarang Regency Regional Devices [4] and Semarang Regent Regulation No. 52 of 2016 on The Position, Organisational Structure, Duties and Functions and working procedures of regional agencies and Pamong Praja Regency Police Unit [5]. The power of local government encompasses the following topics, according to Law No. 23 of 2014. 1) In the system of the Unitary State of the Republic of Indonesia, the local government organizes government affairs according to the principle of autonomy and assistance duties with the principle of autonomy as broad as possible; 2) The local government carries out concurrent government affairs submitted by the central government to be the basis for the implementation of regional autonomy based on the principle of the task of implementation, 3) The governments are responsible for conducting out the state government's business, that is under the president's authority and is assigned to the governorship and regent/mayor, who are paid from the government budget (APBN).

By granting autonomy to the Region, it allows the Region concerned to organise and take care of its household to increase the usefulness and results for the implementation of government in the framework of service to the community. To be able to organise optimal regional autonomy, sufficient funds are needed. Some of the funds are sought by the area itself, namely The Original Regional Income, which must be enough to benefit its household [6]. Theoretically, decentralisation policies will further improve services to the community because autonomous regions receive more authority and are closer to the people who need assistance. The implementation of regional autonomy policy is not a simple thing because the performance of the regional autonomy policy will be at least related to five items, namely (1) regional authority, (2) regional institutions, (3) regional staffing, (4) regional management and (5) regional legal products. A region with sufficient regional income will easily organise its household affairs, and community prosperity will also be created. To support the increase in Regional Original Income, efforts are made to increase the number of regional levy receipts in the framework of the realisation of regional autonomy.

Original Local Income is defined as local taxes, local levies, the proceeds of managing segregated regional riches, and other valid Regional Original Income, according to Law No. 33 of 2004. (PAD). Regional Native Income (PAD) becomes an essential factor in creating regional independence, where Regional Original Income (PAD) will be a source of funds from the Region. And Regional Original Income (PAD) is the most critical benchmark for regions' ability to organise and realise regional autonomy. To maximise the Original Income of this 
Region, the local government strives to find potential sources of income while optimising the sources of income that have been collected. Regional Original Income becomes an essential factor in creating regional independence, where Regional Original Income (PAD) is a source of funds from the Region itself.

Government financing in carrying out government and development tasks always requires a reliable source of acceptance. Regional Original Income Independence (PAD) for Regional Revenue will positively impact regional independence to allocate budgets in the Regional Budget (APBD). The government raises the Region's initial income, which comes from local taxes, local levies, earnings from regional asset management, and other legal contributions. However, the value of the outcomes of regional wealth management is nil (empty) and does not exist as support in the yearly reporting of Semarang Regency Original Income. As a result, it has not been able to fully establish a notion that should be owned in the Regional Original Income (PAD) category. The Regional Revenue Management Agency (BPPD) of Semarang Regency which was established based on Semarang Regency Regional Regulation No. 21 of 2016 concerning the Establishment and Arrangement of Semarang Regency Regional Devices[4] and Semarang Regent Regulation No. 52 of 2016 concerning The Position, Organisational Structure, Duties and Functions and work procedures of regional agencies and Pamong Praja Regency Police Unit are implementing elements of the Semarang Regency Regional Government that have s implementing the authority of Regional Autonomy in the management of Semarang Regency Revenue.

With the formulation of strategic planning confirmed to all employees, it is expected that the challenges of climate change in local government can be passed. Some things are the government's obstacles in increasing Regional Original Income, namely the low level of community compliance in paying local taxes and local levies and the lack of regional wealth management results in Semarang Regency. Therefore, the government should improve the management of taxes and provincial levies related to planning, systems, and procedures to implement reporting and supervision and coordination between regional indigenous income management agencies (PAD). Regional revenues, as stated in Government Regulation No. 58 of 2005, include all money receipts through the Regional General Cash Account, which adds to the equity of current funds, which is a regional right in one budget year that does not need to be repaid the Region. Provincial revenues sourced from regional revenues will be used to meet regional spending needs.

In the first quarter of 2019, the realisation of regional revenues in Semarang Regency until March 2019 only reached Rp 407 billion or 21.83 per cent of the target in 2019. This realisation is down from the completion of the mark of the same period the previous year. For that, there needs to be optimisation of regional revenues so that revenue realisation does not decrease. The limitations of the Region's ability to generate local native income (PAD) and the increasing need for funds to finance local government functions require local governments to further increase their local financial independence through the optimisation of local native income, potential sources of regional income must be explored optimally.

\section{Methodology}

In general, legal research distinguishes between data received directly from the public and materials obtained via libraries.[7] Primary data (or fundamental data) is information collected directly from the public, whereas secondary data is information gathered through library resources.[8] Law research comprises primary legal documents, secondary legal materials, and 
tertiary legal materials in secondary data. In this research, The method employed is normative juridical, which entails doing legal research using library resources or secondary data.[9] Legal study that is normative or literature comprises (a) legal principles research, (b) systematic law research, (c) vertical and horizontal synchronization standards research, (d) legal comparison, and (e) legal history research.

The primary legal material, namely binding legal materials, consists of (a) basic norms or basic rules, namely the opening of the 1945 Constitution, (b) basic regulations, covering the body of the 1945 Constitution and the Provisions of the People's Consultative Assembly, (c) Laws and regulations, (d) unconditioned legal materials such as customary law, (e) jurisprudence, (f) treaties, (g) legal materials from the colonial era that still apply such as the criminal code (Criminal Code). Secondary legal material explains primary legal materials such as draft legislation, research results, works from legal circles, etc. The most specialized legal materials, such as dictionaries, encyclopedias, cumulative indices, and shortly, are those that give hints and explanations to primary and secondary legal documents.

\section{Results and Discussion}

\subsection{Regional Original Income of Semarang Regency}

Regional Original Income (PAD) is one of the success factors in achieving regional development goals. This is because PAD determines the capacity of local governments in carrying out government functions, namely carrying out public services (public service functions) and carrying out development (development functions). In achieving this goal, Local governments are granted the ability to decide regional taxes and levies, the outcomes of segregated regional wealth management, and the discretion to set tariffs based on their capacities and other legal sources, under Law Number 28 of 2009 concerning Regional Taxes and Regional Levies. In its implementation, local governments must pay attention to the principles of equity and justice, involve community participation and pay attention to regional potential. Data on Original Local Government Revenue and the realisation of its implementation in 2019 are as follows:

Tabel 1. The Number of Regional Original Income in Semarang Regency in 2019

\begin{tabular}{llcc}
\hline No & \multicolumn{1}{c}{ Name } & $\begin{array}{c}\text { Revenue Plan } \\
\text { (Millions of rupiah) }\end{array}$ & $\begin{array}{c}\text { Realisation of Acceptance } \\
\text { (Millions of rupiah) }\end{array}$ \\
\hline 1 & Original Local Government Revenue & 407.019 & 34.140 \\
& a. Local Taxes & 148.615 & 13.746 \\
& b. Retributions & 34.429 & 3.027 \\
& c. Regional Owned Company Results & 14.383 & - \\
& $\quad$ & \\
& and Separate Regional Asset & & 17.367 \\
& Management & 209.593 & \\
& d. Regional Gov Corporate and & & 164.280 \\
& Management of Separated Reg & & 237 \\
2 & Gov Wealth & 1.384239 & 164.043 \\
& Balanced Budget & 43.419 & - \\
& a. Tax Sharing & 1.001 .565 & - \\
& b. General Allocation Funds & 339.255 & - \\
c. Special Allocation Funds & Other Legal Revenue & 511.696 & \\
& a. Grants & 82.109 & \\
\hline
\end{tabular}




\begin{tabular}{llcc}
\hline No & \multicolumn{1}{c}{ Name } & $\begin{array}{c}\text { Revenue Plan } \\
\text { (Millions of rupiah) }\end{array}$ & $\begin{array}{c}\text { Realisation of Acceptance } \\
\text { (Millions of rupiah) }\end{array}$ \\
\hline b. & $\begin{array}{l}\text { Share of Tax Revenues from } \\
\text { Provinces }\end{array}$ & 153.095 & \\
c. & $\begin{array}{l}\text { Special Adjustment \& Autonomy } \\
\text { Fund }\end{array}$ & 44.330 & \\
d. & $\begin{array}{l}\text { Financial Assistance from the } \\
\text { Province }\end{array}$ & 50.230 & 198.420 \\
\hline \multicolumn{2}{c}{ Total } & 2.302.955 & \\
\hline & &
\end{tabular}

According to the table above, the Government of Semarang Regency's Realisation of Revenue and Expenditure is the realisation/ calculation of Semarang Regency's Regional Revenue and Expenditure Budget in each budget year. The Regional Original Money (PAD) is the income obtained by the Region, which is collected based on local rules in line with the laws and regulations, and used to fund the Region's operations. In the context of decentralisation implementation, the Balance Sum is a cover drawn from state budget resources provided to the Region to fund regional requirements. Other Legal Incomes include funds from the government and/or important organizations, as well as revenue from other areas. Regional Financial Development is directed at improving the ability and usefulness of the overall order, institutions and financial wisdom in supporting the balance of development; Increasing the nation's independence through increasing financial capabilities that are increasingly reliable, efficient and able to meet the demands of development, the creation of an atmosphere that encourages the growth of community initiatives and creativity and the widespread participation of the community in action.

In 2019 the revenue of Semarang Regency reached Rp 2,302,955,000 with details of about $8.39 \%$ contributed from Regional Original Income (PAD), Balance Fund $11.87 \%$ and another Income witch legitimate $0 \%$; so in 2019 , the realisation of the original income of Semarang regency area is around $8.62 \%$ of the revenue plan. This is a decrease in the realisation of the original income of the Semarang regency from the previous year, namely in 2018, with an income plan of Rp. 2,108,013,000 realisation of Rp. 2,117,417,000 or $100.45 \%$, while in 2017 , with an income plan of Rp. 2,058,632 and realisation of Rp. 2,135,227 or $103.72 \%$.

\subsection{The Regional Revenue Management Agency of Semarang Regency implemented a Regional Policy to Increase Regional Original Income}

The results of a descriptive analysis of research on Tax Collection Policy in Increasing Regional Original Income (PAD) are seen from five indicators used in this study. They can be described that on the indicator of fit or conformity, namely, whether the hotel tax collection policy implemented by the Semarang district government impacts increasing Regional Original Income (PAD) of Semarang regency. Following the answers employees answers.[10]

In the effectiveness indicator, namely, whether the policy implemented is effective to solve the problems seen from the results and impact of the policy, it can generally be seen that the hotel tax collection policy is very effective in increasing Regional Original Income (PAD) this can be seen from the impact of the policy. The indicator of efficiency, whether the resources needed to implement the policy are provided or sufficiently available, can be seen from employees' answers quite efficiently. Still, some employees complain about the lack of human resource provision. (4) On the indicator of responsiveness, i.e. whether the policy has responded to the increase in the original income of the Region. The tax collection policy is 
very influential in the face of the increase in Regional Original Income (PAD). The decline shows no consistency in existing tax increases. Taxpayers of private persons or corporate taxpayers, especially miners and the United Nations registered, of course, are expected to be adequately realised and consistently in their realisation per year [11].

Regional Native Income (PAD) is a source of regional income that can be used as benchmarks for a region's economic performance. Local native income (PAD) is the income earned by the Region collected under local regulations following the laws and regulations, including (1) local taxes; (2) local retribution; (3) the results of the management of the wealth of the separate area; and (4) other legitimate PAD, as defined by law number 32 of 2004 on local government and law number 33 of 2004 on the financial balance between the central government and local government. Specifically taxes and local levies, the legal basis of the collection is based on Law No. 34 of 2000 on Changes to Law No. 18 of 1997 on Local Taxes and Local Levies, while its implementation is regulated in Government Regulation No. 65 of 2001 on Local Taxes and Government Regulation No. 66 on Local Levies.

The factors influential in the billboard tax collection process in increasing Regional Original Income in Semarang Regency consist of supporting and inhibitory factors. Supporting factors include; (1) clarity of standards and policy objectives, (2) the availability of resources needed in the implementation of policies such as staff, physical facilities, information and so on, (3) smooth, balanced and clear communication between organisations and implementers, (4) the characteristics of implementing institutions that support the successful implementation of policies, (5) social, economic and political conditions in which the policy is implemented, and (6) the willingness and commitment of implementers to the successful implementation of policies on the ground. In contrast, the inhibiting factors include: (a. socialisation, the community as taxpayers many do not understand the local regulations on billboard taxes, (b). In coordination with relevant agencies, as a result, there is no cooperation and coherence in implementing policies. (c) the attitude of the implementer, in implementing the Regional Regulation, the implementers do not have a high commitment, (d) the weak of law enforcement, the absence of sanctions against taxpayers who neglect to carry out their obligations.

Parking tax management in Semarang Regency is explained by six indicators: planning, implementation, management, reporting, accountability, and supervision activities. From the results of the analysis that has been done, planning activities, performance, management, reporting, accountability and supervision in Semarang Regency can be concluded to have been done well. This means that the management of parking taxes in Semarang Regency has been done well. Parking tax management in Semarang Regency has been done well. For taxpayers, the self-assessment system, calculation and determination of taxes is done alone. For taxpayers of the Official Assessment system, analyses and decisions are carried out by officials of the Regional Revenue Management Agency as outlined in the Regional Tax Decree (SKPD) signed by the Regional Revenue Management Agency Official. For Taxpayer Self-Assessment, which is based on examination or other information, it turns out that the amount of tax owed in the Regional Tax Payable Notification Letter is less than the actual amount, then regional financial agency officials.

The subject of groundwater tax is a private person or entity that takes and uses groundwater. Groundwater taxpayers are private persons or entities that make the taking or utilisation of groundwater. Semarang Regency Regional Regulation number 02 of 2011 on Groundwater Tax article 5, excluded from the object of Groundwater Tax, is the collection and Utilisation of Groundwater for primary household purposes, agricultural irrigation and people's experiments, and worship. 
Groundwater taxpayers are obliged to report the calculation and payment of groundwater taxes owed to a regent or appointed officials. Reporting is submitted using a regional tax payable notification letter within a certain period. Regional tax payable notification letter must be filled in completely, clearly, correctly and signed by the taxpayer. Information and documents that must be included and or attached to the regional tax payable notification letter are determined by the regent. Generally, a provincial tax payable notification letter must be submitted no later than fifteen days after the expiration of the tax period. The regent can extend the delivery period of the regional tax payable notification letter on the taxpayer's request on legitimate and acceptable grounds. The provincial tax payable notification letter.

The Semarang Regency swallow's nest tax policy, the perspective of regional autonomy, is that the Semarang Regency swallow nest tax policy during 2017-2018 is likely not to run optimally. Swallows. Because the Swallow's Nest Tax realisation still does not produce (nil), the government is not serious in implementing the Swallow's Nest Tax Policy 2017-2018 because implementors do not communicate to the target. The authority owned by the implementor is also not done correctly, such as supervision, data collection, and even sanctions. SOP in implementation is also not owned by BP2D Semarang Regency. Obstacles faced by the Semarang Regency government in the performance of taxes include taxpayers who are not domiciled in the city of Ungaran, making it challenging to communicate. A budget for the swallow's nest tax is available but limited, both for socialisation and extension, and maximises communication to the taxpayer by writing to each swallow taxpayer.

Policy formulation related to minerals and rocks Tax in this study, after a sub-district level meeting by the executive then held a district-level meeting with actors who acted as follows: a) Energy Mineral Resources Service b) Environmental agency c) Regional Planning Agency d) Regional Finance Agency e) Forestry f) Licensing Agency g) Regional People's Representative Assembly Representative 2) This district-level meeting discussed the issues and advice on the results of sub-district level meetings that were then classified. 3) In policy formulation is also supported by technology, namely the use of the internet to look for other district regulations as examples and other data needed to support policy formulations. 4) The legislature's next stage of academic study is creating draft local regulations, 5) Sharing with relevant parties is carried out periodically. 6) Actors who play a role in sharing include: a) Regional People's Representative Assembly b) Related agencies c) Community leaders d) Miners 2. Potential Tax of Non-metals and Rocks minerals to increase Regional Original Income (PAD) in Semarang Regency.

\section{Conclusion}

The acquisition of hotel taxes, restaurant taxes, entertainment taxes, billboard taxes, street lighting taxes, parking taxes, groundwater taxes, bird's nest taxes, and fees by the Semarang District Revenue Management Agency, especially in 11 types of regional taxes based on data from the 2017-2018 tax year, is known to be the type of tax that increased in 2018. Building and Land Rights (BPHTB). While municipal tax revenues have declined, the minerals and rocks tax, as well as the earth and building tax, have increased (UN). A reward is required at least every three years of tax against the taxpayers who pay the highest taxes and comply with paying taxes every year. Early identification of the potential 11 types of local taxes should always be done and evaluated, along with the socialisation of online tax programs to make it easier for private or corporate taxpayers to pay their taxes. 


\section{References}

[1] E. E. Supriyanto, Eksistensi Nilai-Nilai Pancasila Dalam Kebijakan Ekonomi Indonesia, 1st ed., no. September. Malang: Literasi Nusantara, 2020.

[2] E. E. Supriyanto, "Revitalization of Pancasila as a Solution to The Problems Faced by The Indonesian Nation,” J. Pendidik. Nusant., vol. 1, no. 2, pp. 52-61, 2021.

[3] S. Syarif and S. Suparno, "Legal Ideal of Pancasila on Legal Politic in the Formulation of Laws and Regulations," 2021, doi: 10.4108/eai.6-3-2021.2306458.

[4] Peraturan Daerah Kabupaten Semarang Nomor 21 Tahun 2016 Tentang Pembentukan dan Susunan Perangkat Daerah Kabupaten Semarang.

[5] Peraturan Bupati Semarang No 52 Tahun 2016 Tentang Kedudukan, Susunan Organisasi, Tugas dan Fungsi, Tata Kerja, dan perincian Tugas Perangkat Daerah Kabupaten Semarang. .

[6] G. T. Allison and M. H. Halperin, "Bureaucratic politics: A paradigm and some policy implications," World Polit., vol. 24, no. S1, pp. 40-79, 1972.

[7] W. M. K. Trochim, Research Methods. 2019.

[8] D. Marsh and P. Furlong, "A skin not a sweater: Ontology and epistemology in political science," Theory methods Polit. Sci., vol. 2, pp. 17-41, 2002.

[9] Z. D. Zaini, "Implementasi Pendekatan Yuridis Normatif dan Pendekatan Normatif Sosiologis dalam Penelitian Ilmu Hukum," Pranata Hukum, vol. 6, no. 2. pp. 117-132, 2011.

[10] R. S. Astuti, H. Warsono, and A. Rachim, Collaborative Governance Dalam Perspektif Administrasi Publik, 1st ed. Semarang: DAP Press, 2020.

[11] N. Sutisna and R. Sara, "Criminal Law Policy and Protection of Witnesses and Victims in Corruption Cases in Government Procurement of Goods and Services," 2021, doi: 10.4108/eai.6-3-2021.2306463. 